\title{
Taxonomy of the Truffles
}

\author{
Samad Jamali
}

\begin{abstract}
Truffles are the hypogeous fruiting bodies of Ascomycete fungi that live in symbiosis with roots of trees such as oaks, hazels, poplar, etc. Due to limited morphological characters, these fungi are difficult to identify at species level. Molecular phylogenetic studies have recently demonstrated that morphological characters of hypogeous Ascomycetes can be unreliable.
\end{abstract}

Keywords: truffles; ascomycetes; fungi

\section{Introduction}

Truffles can be divided into two types: tuber and desert truffles. Truffles are the hypogeous fruiting bodies of Ascomycete fungi that live in symbiosis with the roots of trees such as oaks, hazels, poplar (Harley \& Smith, 1983), some shrubs as Cistus, members of Cistaceae, mainly with Helianthemum species, both annual and perennial (Awameh, Alsheikh, \& Al-Ghawas, 1979; Honrubia, Cano, \& Molina-Ninirola, 1992; Morte, Lovisolo, \& Schubert, 2000; Kovacs, Bagi, Vagvolgy, Kottke, \& Oberwinkler, 2003), and members of Cypraceae (Ammarellou, Saremi, \& Gucin, 2007, Jamali \& Banihashemi, 2012, 2013). Nowadays the taxonomical criteria to identify truffles are size and shape of spores and asci, spore wall ornamentation and structure of the peridium and gleba (Mello, Murat, \& Bonfante, 2006). Due to their limited morphological characteristics,

Received: 15 September 2014

Accepted revised version: 18 November 2014

Published online: 01 December 2014

(C) Samad Jamali (2014)

Publisher: Horizon e-Publishing Group

CITATION

Jamali, S. (2014). Taxonomy of the truffles. Plant Science

Today, 1(4), 219-222. doi: 10.14719/pst.2014.1.4.55

\section{AUTHOR'S AFFILIATION}

Assistant professor of Mycology in Department of Plant Protection, College of Agriculture, Razi University, Kermanshah, Iran.

CORRESPONDENCE

\Dr. Samad Jamali, e-mail: jamali454@yahoo.com these fungi are difficult to identify at species level. Molecular phylogenetic studies have recently demonstrated that morphological characteristics of hypogeous Ascomycetes can be unreliable (Ferdman, Aviram, Roth-Bejerano, Trappe, \& Kagan-Zur, 2005). Other molecular studies of truffles have led to the reclassification of some genera or species (O'Donnell, Cigelnik, Weber, \& Trappe, 1997; Hansen, Lassoe, \& Pfister, 2001).

\section{Traditional taxonomy}

Traditional taxonomy is based on external or internal morphological criteria. Vittadini (1831) was the first to introduce such a classification of truffles and distinguished two groups based on their texture and organoleptic properties. In 1862 the Tulasne brothers published a treastise on truffles classifying them based on microscopic criteria. From the $18^{\text {th }}$ to the $20^{\text {th }}$ century, about 200 species, varieties and forms of truffles were described by mycologists of various countries (Mello et al., 2006). Limited communication means during that time introduced many redundancies so that this number was recently reduced by Ceruti, Fontana, \& Nosenzo, (2003) who considered only 28 species to be valid for Europe. Worldwide the number of truffle species is estimated to be around 60 (Trappe, 1979). Morphological characteristics have been used to describe different species of truffles including size and shape of spores and asci, spore wall ornamentation, structure of the peridium and gleba and organoleptic characteristics (Trappe, 1979; Mello et al., 2006). In 1972, a synoptic key for the Pezizales provided the means to discern the relationship between genera of Tuberales and genera of Pezizales (Korf, 1972). The key contains six major categories of character: ascocarp morphology, peridium, asci, paraphyses, spores and habitat. These criteria are however not sufficient for species with very similar morphological features and that are difficult to identify at the species level (Diez, Manjon, \& Martin, 2002). Biophysical (Papa, Balbi, \& Ausidio, 1987), biochemical (Mouches, Duthil, Poitou, Delmas, \& Bove, 1981; Dupre \& Chevalier, 1991; Palenzona et al., 1990; Cameleyre \& Olivier, 1993; Gandeboeuf, Dupre, \& Chevalier, 1994), olfactory (Pacioni \& Pomponi, 1989), and immunological (Corocher, Polimeni, Giraudi, \& Papa, 1992; 
Neuner-Plattner et al., 1999) tools have been developed in the past to identify and characterize truffle species, but have since been superseded by faster and easier molecular techniques. Also, their use to specifically identify mycorrhiza is limited by the amount of biological material required. In contrast, PCR-based DNA detection can be performed on minute amounts of tissue.

\section{Molecular Taxonomy}

Desert truffles were traditionally grouped into the Terfeziaceae family of fungi, within the order Tuberales. In recent years, molecular phylogenetic studies demonstrated that the morphological characteristics of hypogeous Ascomycetes can be misleading (Ferdman et al., 2005) due to a reduction in the macromorphological characteristics needed for distinguishing their related epigeous taxa. Thus O'Donnell et al., (1997) and Hansen et al., (2001) demonstrated that certain hypogeous fungi show greater affinity to epigeous members of the Pezizales than to other hypogeous species. It seems that on at least 15 independent occasions epigeous fungi within the Pezizales have evolved the below-ground fruiting mechanisms required to become truffles (Hansen, 2001). Other molecular studies on truffles have led to the reclassification of some genera or species (O'Donnell et al., 1997; Norman \& Egger, 1999; Percudani et al., 1999; Roux et al., 1999; Hansen et al., 2001 and Diez et al., 2002). Some of these investigations confirm earlier morphological findings. Of 31 genera of hypogeous Ascomycotina accepted, one is assigned to the monotypic order Elaphomycetales and the rest are placed in the Pezizales. The polyphyletic order Tuberales is abandoned. Nine families of the Pezizales include hypogeous species: Helvellaceae, Pezizaceae, Ascobolaceae, Pyronemataceae, Balsamiaceae, Geneaceae, Terfeziaceae, Tuberaceae and Garbomycetaceae (Trappe, 1979). The hypogeous ascomycete fungi (truffles) are now distributed among six Pezizalean families: Glaziellaceae, Discinaceae-Morchellaceae, Helvellaceae, Tuberaceae, Pezizaceae, and Pyronemataceae, comprising 38 genera (Hansen et al, 2001). The family Tuberaceae, which includes the most highly prized (and priced) forest truffles is the single family containing only underground species (Hansen et al, 2001). The best known and appreciated genera Terfezia and Tirmania were shown to belong to the Pezizaceae rather than to the distinctly hypogeous Terfeziaceae family, which has been abolished (Norman \& Egger, 1999; Percudani et al., 1999). Similarly, the monophyletic origin of some members of Terfezia and Tirmania was confirmed by Diez et al., (2002). The genus Choiromyces was transferred from the Pezizaceae to the Tuberaceae (O'Donnell et al. 1997, Percudani et al. 1999), although one Choiromyces species, C. echinulatus, was removed from this genus and restored to the Pezizaceae under a new name, Eremiomyces echinulatus (Ferdman et al., 2005). Similarly, two species were removed from the
Terfezia genus: Terfezia terfezioides, reinstated as Mattirolomyces terfezioides (Percudani et al., 1999; Diez et al., 2002) and Terfezia pfeilii, renamed Kalaharituber pfeilii (Ferdman et al., 2005). Such molecular data are not yet available for Mycoclelandia (an Australian desert genus with two species), but it was assigned to the Pezizaceae because of its strongly amyloid asci (Trappe, 1979; Trappe \& Beaton, 1984). Cryptic species (truffles that are morphologically identical but molecularly distinct and distant from each other) are coming to light, including a group of three discovered within the T. boudieri desert truffle complex (Ferdman et al, 2005). The Pezizaceae includes (among others) the following hypogeous genera: Eremiomyces, Hydnotryopsis, Kalaharituber, Mattirolomyces, Pachyphloeus, Peziza, Ruhlandiella, Stephensia, Terfezia, and Tirmania (Laessøe \& Hansen, 2007). Of these Terfezia is the held in the highest regard for eating; followed by Kalaharituber, Tirmania, and Mattirolomyces.

\section{Molecular tools for identification of truffles}

Much of the molecular research aimed at identifying fungi in general (Gardes, White, Fortin, Bruns, \& Taylor, 1991; Henrion et al., 1992; Buscot et al., 1996; Mello et al., 1996; Chillali, Wipf, Guillaumin, Mohammed, \& Botton, 1998) and truffles in particular (Henrion et al., 1994; Paolocci, Angelini, Cristofari, Granetti, \& Arcioni, 1995; Paolocci, Rubini, Granetti, \& Arcioni, 1999) relies on comparison of sequences and RFLP patterns of the ITS region. Several phylogenetic studies of truffles have also used this DNA region (Roux et al., 1999; Diez et al., 2002). Other molecular phylogenetic studies have been based on sequences from the $18 \mathrm{~s}$ and the $28 \mathrm{~S}$ (LSU) rRNA genes with or without the ITS region (e.g. ODonnell et al., 1997; van Tuinen, Jacquot, Zhao, Gollotte, \& Gianinazzi- Pearson, 1998; Norman \& Egger, 1999; Percudani et al., 1999; Hansen et al., 2001). In recent years, several studies have focused on truffle phylogeny using several loci, and these have allowed the main species to be clearly defined (Halasz et al., 2005; Mello et al., 2005; Paolocci, Rubini, Riccioni, Topini, \& Arcioni, 2004; Wang et al., 2006; Weden, Danell, \& Tibell, 2005; Zhang, Yang, \& Song, 2005). As an example, Wang et al. (2006) investigated the European and Asian truffle phylogeny by sequencing several genomic loci. The intraspecific ITS variability in $T$. magnatum, T. melanosporum, T. mesentericum, T. aestivum, and T. indicum has been widely investigated (Mello et al., 2005; Murat et al., 2004; Paolocci et al., 2004; Wang et al., 2006; Weden et al., 2005; Zhang et al., 2005), and it has been revealed that the most expensive species ( $T$. magnatum and T. melanosporum) have a low level of ITS variability. On the other hand, T. mesentericum, $T$. aestivum, and T. indicum showed a higher diversity level. ITS regions are present in multiple copies and tend to be similar within and variable between fungal species. Species-specific primers have been designed for several 
Tuber species by analyzing the ITS region (Amicucci, Zambonelli, Giomaro, Potenza, \& Stocchi, 1998; Henrion et al., 1994; Paolocci et al., 1995, 1997; Rubini et al., 1998) and protocols for extraction of DNA from fruitbodies have been optimized (Sejalon-Delmas et al., 2000). Other PCR-based methods have also been used: RAPD (Gandeboeuf et al., 1997), microsatellites (Lanfranco, Wyss, Marzachi, \& Bonfante, 1993), and the corresponding primers specifically designed. The rRNA genes present different levels of conservation which can be exploited to analyze any desired phylogenetic level (Hillis \& Dixon, 1991). Regarding the systematics of desert truffles, the use of morphological features is problematic, because of the reduced set of morphological characteristics and their homoplasy. Ascocarp features are homoplastic as a result of parallel evolution of independent lineages of epigeous/hypogeous fruit bodies during the evolutionary history of the Pezizales (Trappe, 1979).

\section{Conclusion}

Morphological characters have been used to describe different species of truffles. Due to limited morphological characters, these fungi are difficult to identify at species level. Molecular phylogenetic studies have recently demonstrated that morphological characters of hypogeous Ascomycetes can be unreliable. rDNA contains a mosaic of highly conserved and variable regions that enable inter- and intra-specific comparisons. These genes occur in multiple arrays, and mutations in their noncoding region occur at a rate that approximates the rate of species emergence. Over time, such mutations become fixed through unequal crossing over and gene conversion, a process that is commonly termed concerted evolution. Within a species ITS tend to be distinct and monomorphic. They, therefore, are suitable for species discrimination across a wide range of organisms including truffles and other fungi.

\section{References}

Amicucci, A., Zambonelli, A., Giomaro, G., Potenza, L., \& Stocchi, V. (1998). Identification of ectomycorrhizal fungi of the genus Tuber by species-specific ITS primers. Mol. Ecol., 7, 273-277. doi: 10.1046/j.1365-294X.1998.00357.x

Ammarellou, A. Saremi, H. and Gucin, F. (2007). Evaluation of morphology, cytology and mycorrhizal relationships of desert truffles in Iran. Paki. J. Bio. Sci., 10, 1486-1490. doi: 10.3923/pjbs.2007.1486.1490

Awameh, M.S., Alsheikh, A., and Al-Ghawas, S. (1979). Mycorrhizal synthesis between Helianthemum ledifolium, $H$. salicifolium and four species of the genera Terfezia and Tirmania using ascospores and mycelial cultures obtained from ascospore germination. Proc. 4th North Amer. Conf. Mycorrhizae, Colorado State University, Forth Collins (USA).

Buscot, F., Wipf, D., Di Battista, C., Munch, J. C., Botton, B. \& Martin, F. (1996). DNA polymorphism in morels: PCR/RFLP analysis of the ribosomal DNA spacers and microsatellite-primed PCR. Mycological Reseurclz,
10.1016/S0953-7562(96)80101-8

Cameleyre, I. \& Olivier, J. M. (1993). Evidence for intraspecific isozyme variation among French isolates of Tuber melanosporum Vitt. FEMS Microbiol. Lett. 110, 159-162. doi: 10.1111/j.1574-6968.1993.tb06313.x

Ceruti, A., Fontana, A. \& Nosenzo, C. (2003). Le specie europee del genere Tuber. Una revisione Storica. Monografie XXXVII. Regione Piemonte, Italy.

Chillali, M., Wipf, D., Guillaumin, J. J., Mohammed, C. \& Botton, B. (1998). Delineation of the European Armillaria species based on the sequences of the internal transcribed spacer (ITS) of ribosomal DNA. New Phytologist, 138, 553-561. doi: 10.1046/j.1469-8137.1998.00124.x

Corocher, N., Polimeni, C., Giraudi, G., \& Papa, G. (1992). Sviluppo di un metodo immunoenzymatico (ELISA) per la caracterizzazione di ectomicorrize di Tuber magnatum e T. albidum. Micol. Veg. Mediterr., 7, 151-158.

Diez, J., Manjon, J. L. \& Martin, M. F. (2002). Molecular phylogeny of the mycorrhizal desert truffles (Terfezia and Tirmania), host specificity and edaphic tolerance. Mycologia. 94(2), 247-59. doi: $10.2307 / 3761801$

Dupre, C. \& Chevalier, G. (1991). Analyse electrophore'tique des prote ines fongiques de diffe'rents Tuber en association ou non avec Coryllus avellana. Cryptogamie Mycol., 12, 243-250.

Ferdman, Y., Aviram, S., Roth-Bejerano, N., Trappe, J. M., \& Kagan-Zur, V. (2005). Phylogenetic studies of Terfezia pfeilii and Choiromyces echinulatus (Pezizales) support new genera for southern African truffles: Kalaharituber and Eremiomyces. Mycol. Res., 109, 237-245. doi: 10.1017/S0953756204001789

Gandeboeuf, D., Dupre, C. \& Chevalier, G. (1994). Diffe'renciation des truffes Europe'ennes par l'analyse des isoenzymes. Acta Bot. Gallica. 141, 455-463. doi: 10.1080/12538078.1994.10515183

Gandeboeuf, D., Dupre, C., Roeckel-Drevet, P., Nicolas, P. \& Chevalier, G. (1997). Grouping and identification of Tuber species using RAPD markers. Can. J. Bot., 75, 36-45. doi: 10.1139/b97-005

Gardes, M. White, T. J., Fortin, J. A., Bruns, T. D. \& Taylor, J. W. (1991). Identification of indigenous and introduced symbiotic fungi in ectomycorrhizae by amplification of nuclear and mitochondria1 ribosomal DNA. Can. J. Bot., 69, 180-190. doi: 10.1139/b91-026

Halász, K., Bratek, Z., Szego, D., Rudnoy, S., Racz, I., Lasztity, D. \& Trappe, J. M. (2005). Tests of species concepts of the small, white, European group of Tuber spp. based on morphology and rDNA ITS sequences with special reference to Tuber rapaeodorum. Mycological Progress, 4, 281-290. doi: 10.1007/s11557-006-0132-6

Hansen, K., Lassoe, T. \& Pfister, D. H. (2001). Phylogenetics of the Pezizaceae, with emphasis on Peziza. Mycologia, 93, 958-990. doi: $10.2307 / 3761760$

Harley, J. L. \& Smith, S. E. (1983). Mycorrhizal Symbiosis. Academic Press. London.

Henrion, B., Chevalier, G., \& Martin, F. (1994). Typing truffle species by PCR amplification of the ribosomal DNA spacers. Mycol. Res., 98, 3743. doi: 10.1016/S0953-7562(09)80333-X

Henrion, B., Le Tacon, F. \& Martin, F. (1992). Rapid identification of genetic variation of ectomycorrhizal fungi by amplification of ribosomal RNA genes. New Pzytologist, 122, 289-298. doi: 10.1111/j.1469-8137.1992.tb04233.x

Hillis, D. M. \& Dtxon, M. T. (1991). Ribosomal DNA: molecular evolution and phylogenetic inference. The Quurterly Rrvieirr of Biology, 66, 141-147.

Honrubia M, Cano A., \& Molina-Niñirola C. (1992). Hypogeous fungi from Southern Spanish semi-arid lands. Persoonia, 14, 647-653. 
Jamali, S. \& Banihashemi, Z. (2012). Hosts and distribution of desert truffles in Iran, based on morphological and molecular criteria. J. Agr. Sci. Tech., 14, 1379-1396.

Jamali, S., \& Banihashemi, Z. (2013). Nested-PCR for Detection Terfezia claveryi in Roots of Helianthemum species in Field and Greenhouse Conditions. Journal of Agricultural Science and Technology. Vol. 15.

Korf, R. P. (1972). Synoptic key to the genera of the Pezizales. Mycologia, 64, 937-994. doi: 10.2307/3758070

Kovacs, G., Bagi, I., Vagvolgy, Cs., Kottke, I. \& Oberwinkler, F. (2003). Studies on the root associations of the truffle Terfezia terfezioides. Acta Microbio. Imm. H. 49(2-3), 207-213.

Laessoe, T. \& Hansen, K. (2007). Truffle trouble: what happened to the Tuberales?. Mycological Research III, 1075-1099. doi: 10.1016/j.mycres.2007.08.004

Lanfranco, L., Wyss, P., Marzachi, C. \& Bonfante, P. (1993). DNA probes for identification of the ectomycorrhizal fungus Tuber magnatum. Pico. FEMS Microbiol. Lett., 114, 245-252. doi: 10.1111/j.1574-6968.1993.tb06581.x

Mello, A., Murat, C. \& Bonfante, P. (2006). Truffles: much more than a prized and local fungal delicacy. FEMS Microbiol. Lett. 260, 1-8. doi: 10.1111/j.1574-6968.2006.00252.x

Mello, A., Murat, C., Gavazzana, V., Vizzini, A. \& Bonfante, P. (2005). Tuber magnatum Pico, a species of limited geographical distribution: its genetic diversity inside and outside a truffle ground. Environ Microbiol 7, 55-65. doi: 10.1111/j.1462-2920.2004.00678.x

Mello, A., Nosenzo, C., Meotto, F. \& Bonfante, P. (1996). Rapid typing of truffle mycorrhizal roots by PCR amplification of the ribosomal DNA spacers. Mycorrhiza, 6, 417421. doi: $10.1007 / \mathrm{s} 005720050141$

Morte, A., Lovisolo, C. \& Schubert, A. (2000). Effect of drought stress on growth and water relations of the mycorrhizal association Helianthemum almeriense - Terfezia claveryi. Mycorrhiza, 10, 115-119. doi: $10.1007 / \mathrm{s} 005720000066$

Mouches, C., Duthil, P., Poitou, N., Delmas, J. \& Bove, J. M. (1981). Caracterisation des especes truffieres par analyse de leurs proteines en gel de polyacrylamide et application de ces techniques a la taxonomie des champignons. Mushroom Sci., 11, 819-831.

Murat, C., Diez, J., Luis, P., Delaruelle, C., Dupre, C., Chevalier, G., Bonfante, P. \& Martin, F. (2004). Polymorphism at the ribosomal DNA ITS and its relation to postglacial re-colonization routes of the Perigord truffle Tuber melanosporum. New Phytologist, 164, 401-411. doi: 10.1111/j.1469-8137.2004.01189.x

Neuner-Plattner, I., Grabher, T., Hall, I. R., Stoffler, G., Griffin, F. \& Haselwandter, K. (1999). A comparison of immunological assays for the identification of Tuber spp. and other edible ectomycorrhizal fungi. Mycol., Res. 103, 403-412. doi: $10.1017 /$ S0953756298007394

Norman, J. E. \& Egger, K. N. (1999). Molecular phylogenetic analysis of Peziza and related genera. Mycologia, 91, 820-829. doi: $10.2307 / 3761535$

O'Donnell, K., Cigelnik, E., Weber, N. S. \& Trappe, J. M. (1997). Phylogenetic relationships among ascomycetous truffles and true and false morels inferred from $18 \mathrm{~S}$ and $28 \mathrm{~S}$ ribosomal DNA sequence analysis. Mycologia, 89, 48-65. doi: 10.2307/3761172

Pacioni, G. \& Pomponi, G. (1989). Chemotaxonomy of some Italian species of Tuber. Micol. Veg. Mediterr., 4, 63-72.

Palenzona, M., Biocca, E., Nascetti, G., Ferrara, A. M., Mattiucci, S., D'Amelio, S. \& Balbo, T. (1990). Studi preliminari sulla tipizzazione genetica (sistema gene enzyma) di speciesdel genere Tuber. In Atti del II congresso internazionale sul tartuffi; Granetti, B., Bencivaga, M., Eds.; Peruggia, pp 53-58.
Paolocci F, Rubini A, Granetti B, \& Arcioni, S. (1997). Typing Tuber melanosporum and Chinese black true species by molecular markers. FEMS Microbiology Letters, 153,: 255-260. doi: 10.1111/j.1574-6968.1997.tb12582.x

Paolocci F, Rubini A, Granetti B, \& Arcioni, S. (1999). Typing Tuber melanosporum and Chinese black true species by molecular markers. FEMS Microbiology Letters 153, 255-260. doi: 10.1111/j.1574-6968.1997.tb12582.x

Paolocci, F., A. Rubini, C. Riccioni, F. Topini, \& S. Arcioni, S. (2004). Tuber aestivum and Tuber uncinatum: two morphotypes or two species? FEMS Microbiol. Lett. 235, 109-115. doi: 10.1111/j.1574-6968.2004.tb09574.x

Paolocci, F., Angelini, P., Cristofari, E., Granetti, B. \& Arcioni, S. (1995). Identification of Tuber spp. and corresponding ectomycorrhizas through molecular markers. Journal of the Science of Food and Agriculture, 69, 511-517. doi: 10.1002/jsfa.2740690416

Papa, G.; Balbi, P. \& Ausidio, G. (1987). Preliminary study of fungal spores by pyrolysis-gas chromatography. J. Anal. Appl. Pyrolysis, 11, 539-548. doi: 10.1016/0165-2370(87)85052-0

Percudani, R., Trevisi, A., Zambonelli, A. \& Ottanello, S. (1999). Molecular phylogeny of truffles (Pezizales: Terfeziaceae, Tuberuceae) derived from nuclear rDNA sequence analysis. Mole. Phylog. Evol., 13, 169-180.

Roux, C., Sejalon-Delrnas, N., Martins, M., Parguey-Leduc, A., Dargent, R. \& Becard, G. (1999). Phylogenetic relationships between European and Chinese truffles based on parsimony and distance analysis of ITS sequences. FEMS Microbiol. Lett. 180, 147-155. doi: 10.1111/j.1574-6968.1999.tb08789.x

Rubini, A., Paolocci, F., Granetti, B. \& Arcioni, S. (1998). Single step molecular characterization of morphologically similar black truffle species. FEMS Microbiol. Lett. 164, 7-12. doi: 10.1111/j.1574-6968.1998.tb13060.x

Sejalon-Delmas, N., Roux, C., Martins, M., Kulifaj, M., Becard, G., \& Dargent, R. (2000). Molecular tools for the identification of Tuber melanosporum in agroindustry. J. Agric. Food Chem., 48, 2608-2613. doi: 10.1021/jf9910382

Trappe, J. M. \& Beaton, G. (1984). Mycoclelandia nom. Nov. (hypogeous Ascomycotina), a replacement for the pre-empted generic name Clelandia. Transactions of the British Mycological Society, 83, 535-536. doi: 10.1016/S0007-1536(84)80060-1

Trappe, J. M. (1979). The orders, families, and genera of hypogeous ascomycotina (truffles and their relatives). Mycotaxon. IX, 297-340.

van Tuinen, D. Jacquot, E., Zhao, B., Gollotte, A. \& Gianinazzi- Pearson, V. (1998). Characterization of root colonization profiles by a microcosm community of arbuscular mycorrhizal fungi using $28 \mathrm{~S}$ DNA-targeted nested PCR. Molecular Ecology, 7, 879-887. doi: 10.1046/j.1365-294x.1998.00410.x

Vittadini, C. (1831). Monographia tuberacearum. Felicis rusconi, Milan.

Wang, Y. J., Tan, Z. M., Zhang, D. C., Murat, C., Jeandroz, S. \& Le Tacon, F. (2006). Phylogenetic and populational study of the Tuber indicum complex. Mycological Research, 110, 1034-1035. doi: 10.1016/j.mycres.2006.06.013

Weden, C., Danell, E. \& Tibell, L. (2005). Species recognition in the truffle genus Tuber-the synonyms Tuber aestivum and Tuber uncinatum. Environ. Microbiol. 7, 1535-1546. doi: 10.1111/j.1462-2920.2005.00837.x

Zhang, L., Yang, Z. I. \& Song, D. S. (2005). A polygenetic study of commercial Chinese truffles and their allies: taxonomic implications. FEMS Microbiol Lett., 245, 85-92. doi: 10.1016/j.femsle.2005.02.028.

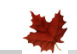

